\title{
Reforms of US energy labs a 'daunting task'
}

Washington. The task force set up by Hazel O'Leary, the US Secretary of Energy, to advise her on "alternative futures" for the Department of Energy's vast network of laboratories has been warned that efforts at reform face great and perhaps insurmountable difficulties.

The panel has also been told by a former senior scientific adviser to the Carter administration that a crisis of identity in the laboratories reflects a similar crisis facing the department itself, which Carter established in the wake of the Middle East oil crisis in the 1970s.

The task force on the laboratories is chaired by Robert Galvin of the electronics company Motorola, and is due to report next
February. O'Leary sees its report as a preemptive strike that could help her to reform the laboratories before Congress looks for more drastic remedies. But with the laboratory network providing high-technology jobs across so many states and congressional districts, her concern may be misplaced.

The network employs 30,000 engineers and scientists and tens of thousands of support staff. It is made up of the three atomic weapons laboratories - Los Alamos and Sandia in New Mexico and Lawrence Livermore, California - as well as a group of smaller but still substantial facilities, such as Fermilab and Argonne in Illinois, and Brookhaven in New York state.

\section{German minister takes on Greens}

Munich. In a direct challenge to the antinuclear policies of the state of Hessen, the German federal environment minister, Klaus Töpfer, has promised to order the state government to grant permission for the completion of a new production plant for mixed oxide (MOX) fuel elements for nuclear reactors.

Construction of the plant, which is located in Hanau and which would have been Germany's only national source of MOX fuel elements, has been suspended at the demand of the state government. But utility companies are doubtful about the impact of Töpfer's challenge, as they feel that he lacks the political stamina for the lengthy battle that would be required to restart the manufacture of fuel elements.

MOX production in Germany, which is controlled by Siemens, has fallen foul of the Social Democrat (SDP)/Green coalition that took control of the government of Hessen in 1991 . Both parties are committed to phasing out nuclear power in Germany.

Most of Germany's 20 nuclear reactors now use MOX elements in addition to standard uranium elements. But the original MOX production facility at Hanau was closed down in 1991 by the state environment minister, Josef Fischer, a member of the Green party, after two relatively minor contamination incidents.

Fischer has also continued to oppose the development of the new plant, which would have quadrupled the capacity of MOX fuel produced to more than 100 tonnes per year, and was originally scheduled to start production in 1992.

Siemens had continued to contest the enforced closure of the old plant. Last week, however, it decided to cut its losses and accept that the plant should be closed permanently. Most of the costs of keeping the plant open but unproductive, estimated at more than DM100 million, had been borne by utilities. These have now agreed that the old plant should be closed, and are negotiating contracts with British Nuclear Fuels (BNFL) in Britain and Cogema in France to produce 300 tonnes of MOX fuel.

Who will produce the remaining 600 tonnes needed to use up the plutonium to be extracted from waste fuel from Germany's reactors depends on the outcome of the battle over the new German MOX plant. Siemens and the utilities have already invested more than DM1 billion in the plant, which is 95 per cent complete and would take around two years to bring into production once construction work started again.

The companies are keen to see a return on their investment as soon as possible. The plant's director, Jürgen Krellmann, claims that permission to complete and operate it is being withheld for purely political reasons. But a spokesperson for the Hessen environment ministry insists that the ministry's sole concern is for the safety of plant workers and the local population.

Töpfer is now trying to break the stalemate. But the situation is not straightforward. Although his federal ministry has ultimate responsibility for nuclear power in Germany, the state government is responsible for safety. He accuses the Hessen government of being technologiefeindlich (hostile to technology), but may find it difficult in practice to force his will on Fischer, as he must issue individual orders to approve each technical step in the building programme, and this could amount to 500 separate orders.

Instead, the utilities are hoping for a change in political mood after the October federal elections and next spring's Hessen state elections. But this cannot be guaranteed. The SDP, which is currently leading the opinion polls for the federal elections, is committed to phasing out nuclear power, and promises to ban the production and eventually the use of MOX fuel elements all together.
At the panel's first meeting two weeks ago, Galvin says that hearing the experts' warnings was a "valuable process" for the panel, and still believes that the time is ripe for reform of the laboratories. "This is a window of time when it is appropriate for people to listen to us," he says. "We are hoping that because the Cold War is over, budgets are tight, and there's so much interest in industrial competitiveness, people will say that it is time to do something different."

But solutions will be hard to find to the fundamental problem facing the laboratories, namely that government funding for their core tasks of developing both nuclear weapons and energy technologies has been heavily cut back, and replacement options lack credibility.

Lewis Branscomb of Harvard University told the members of the panel that their work had been done many times before, but without any effect: previous studies had been "technocratic analyses that failed to take account of the political context" of the laboratories, he said.

Branscomb said that talk of increased 'technology transfer' out of the laboratories was "the wrong paradigm" for their future. "It implies that there are industrially valuable technologies in the laboratories that need to be pushed [into the marketplace], and that is not the case."

Branscombexpressed concern that moves to save money in the network would have a greater effect on good science laboratories than on the larger but arguably less useful weapons laboratories, as the former had less political clout.

He also came close to calling for the Department of Energy itself to be broken up, arguing that the problem of the laboratories is directly linked to the problems that the department faces. "There is an identity crisis in the labs because there is an identity crisis in the department,"Branscomb said. Both seem equally adrift, with no energy crisis to solve or atomic bombs to build.

Congress is also wrestling with the question of a new mandate for the laboratories. It may pass a bill this summer, if the chairman of the House of Representatives Science Committee, George Brown (Democrat, California), can sort out a demarcation dispute with John Dingell (Democrat, Michigan) chairman of the Energy and Commerce Committee and agree on a House version that can be reconciled with a bill already passed by the Senate.

Some voices may demand drastic action. Roscoe Bartlett (Republican, Maryland), for example, is said to be considering moving an amendment on the floor of the House calling for some of the laboratories to be closed down. But even in this cost-cutting Congress, there is no groundswell of support for such a measure. Colin Macilwain 